\title{
Critical Steps to be Taken into Consideration Before Quantification of $\beta$-Amyloid and Tau Isoforms in Blood can be Implemented in a Clinical Environment
}

Hugo Marcel Vanderstichele - Charlotte E. Teunissen •

Eugeen Vanmechelen

Received: September 12, 2019 /

(c) The Author(s) 2019

\section{ABSTRACT}

This review aims to document difficulties, limitations, and pitfalls when considering protein analysis in blood samples. It proposes an improved workflow for design, development, and validation of (immuno)assays for blood proteins, without providing reflections on a potential hypothesis of the origin of protein mismetabolism and deposition. There is a special focus on assay development for quantification of $\beta$-amyloid $(A \beta)$ and tau in blood for diagnostic use or for integration in clinical trials in the field of Alzheimer's disease (AD).

Keywords: Assay; Blood; Biomarker panel; $\beta$ Amyloid; Tau; Validation

Enhanced Digital Features To view enhanced digital features for this article, go to https://doi.org/10.6084/ m9.figshare.9995633.

H. M. Vanderstichele ( $\square)$

Biomarkable, Ghent, Belgium

e-mail: hugo.vanderstichele@biomarkable.be

C. E. Teunissen

Amsterdam University Center, Amsterdam, The

Netherlands

E. Vanmechelen

Key4AD, Eke, Belgium

\section{Key Summary Points}

Blood biomarker panels can be used in the field of Alzheimer's disease (AD) as an early screening tool for subjects at risk for being affected by amyloidopathy in their brains.

Future blood biomarker panels for AD will likely consist of the ratio of ß-amyloid(Aß)(1-42)/Aß(1-40), combined with proteins which reflect other pathological processes of Alzheimer's disease $(\mathrm{AD})$.

In this review, several gaps are identified for implementation of blood biomarker panels in clinical routine or clinical trials, including more stringent acceptance criteria for validation, better standard operating procedures for collection, storage, and testing of biological samples, as well as more stringent selection criteria and characterization of antibodies for inclusion in the assay design.

Analytical validation and biological/clinical validation need to be combined to ultimately arrive at tests with optimal clinical value for a specific context-of-use. 


\section{INTRODUCTION}

Alzheimer's disease (AD) is a growing health problem of the aging population. The number of subjects with $\mathrm{AD}$, the most prevalent cause of dementia ( $>60 \%$ of the cases), will triple by 2050 [1]. Dementia is a syndrome with a complex pathophysiology, characterized by a heterogeneous group of clinical features and pathological hallmarks (e.g., amyloidopathy, tauopathy, synapse loss, oxidative stress, inflammation). Each hallmark is reflected in key proteins that can be measured in biological fluids [27], such as $A \beta$ for plaques, (phospho)tau proteins for tangles, and synapse proteins for synapse loss. $\mathrm{AD}$ is currently defined as a disease with a long preclinical phase (20-30 years) [60], followed by periods of subjective cognitive impairment, mild cognitive impairment (MCI), and, finally, AD. Inter-individual differences in the progression rate of the disease are modulated in part by the genetic profile, the cognitive reserve, and comorbid brain pathologies [19]. Biomarker ${ }^{1}$ panels will likely be useful to stratify patients, for example, in subgroups with different clinical progression profiles or in subgroups with an enhanced likelihood to benefit from treatment directed to specific protein targets. However, much more information is needed for a better understanding of the correlation between changes in biomarker concentrations and the pathophysiology, disease progression, cognition, risk profiling, and the relationship with daily living activities. There is still an inadequate understanding of the pathophysiology of the disease process. Disease-modifying drugs are not available yet [13].

In this review, we will start with an introduction into the state of the art of possibilities for blood biomarker analysis for use in the field of AD. Next, we will discuss different steps in the assay development workflow [from target identification to critical raw material

\footnotetext{
${ }_{1}$ A biomarker is an indicator of normal biological processes, pathogenic processes, or responses to an exposure or intervention, including therapeutic interventions. A biomarker is not an assessment of how a patient feels, functions, or survives (https://www.ncbi. nlm.nih.gov/books/NBK326791/pdf/Bookshelf_NBK326 791.pdf).
}

characterization, assay design \& validation, and generation of standard operating procedures (SOP)]. We will describe a broad range of topics which have to be taken into account during the development phase of protein assays. Figure 1 provides a general overview of aspects with potential influence on the design of blood biomarker test methods and their relationship with each other. This information is important to validate a product with a defined context of use $\left(\mathrm{COU}^{2}\right)$, potential customers, and predefined acceptance criteria for several performance parameters. This article is based on previously conducted studies and does not contain any studies with human participants or animals performed by any of the authors.

\section{CURRENT STATE OF DEMENTIA DIAGNOSIS. POSSIBILITIES FOR IMPROVEMENT USING BLOOD ANALYSIS}

AD pathology was first described in 1906 based on the analysis of brain tissue from a patient by silver staining [2]. Until the early 80 s, AD diagnosis was based solely on clinical evaluations. A definite diagnosis could only be made by postmortem confirmation in brains of affected subjects of the presence of plaques and neurofibrillary tangles [55]. Autopsy data showed that neuritic plaques might be present also in brains of subjects with other types of neurologic conditions or in older people with normal cognition [30]. So, neuropathological results should be viewed more critically and need to integrate several (new) disease patterns [42].

During the last decade, in vivo diagnosis became possible through $\mathrm{A} \beta$-positron emission tomography (A $\beta$-PET) imaging or by

\footnotetext{
${ }^{2}$ Context of use: A statement that fully and clearly describes the way the medical product development tool is to be used and the medical product developmentrelated purpose of the use. Intended use: The specific clinical circumstance or purpose for which a medical product or test is being developed. In the regulatory context, it refers to the objective intent of the persons legally responsible for the labeling of medical products (https://www.ncbi.nlm.nih.gov/books/NBK326791/pdf/ Bookshelf_NBK326791.pdf).
} 


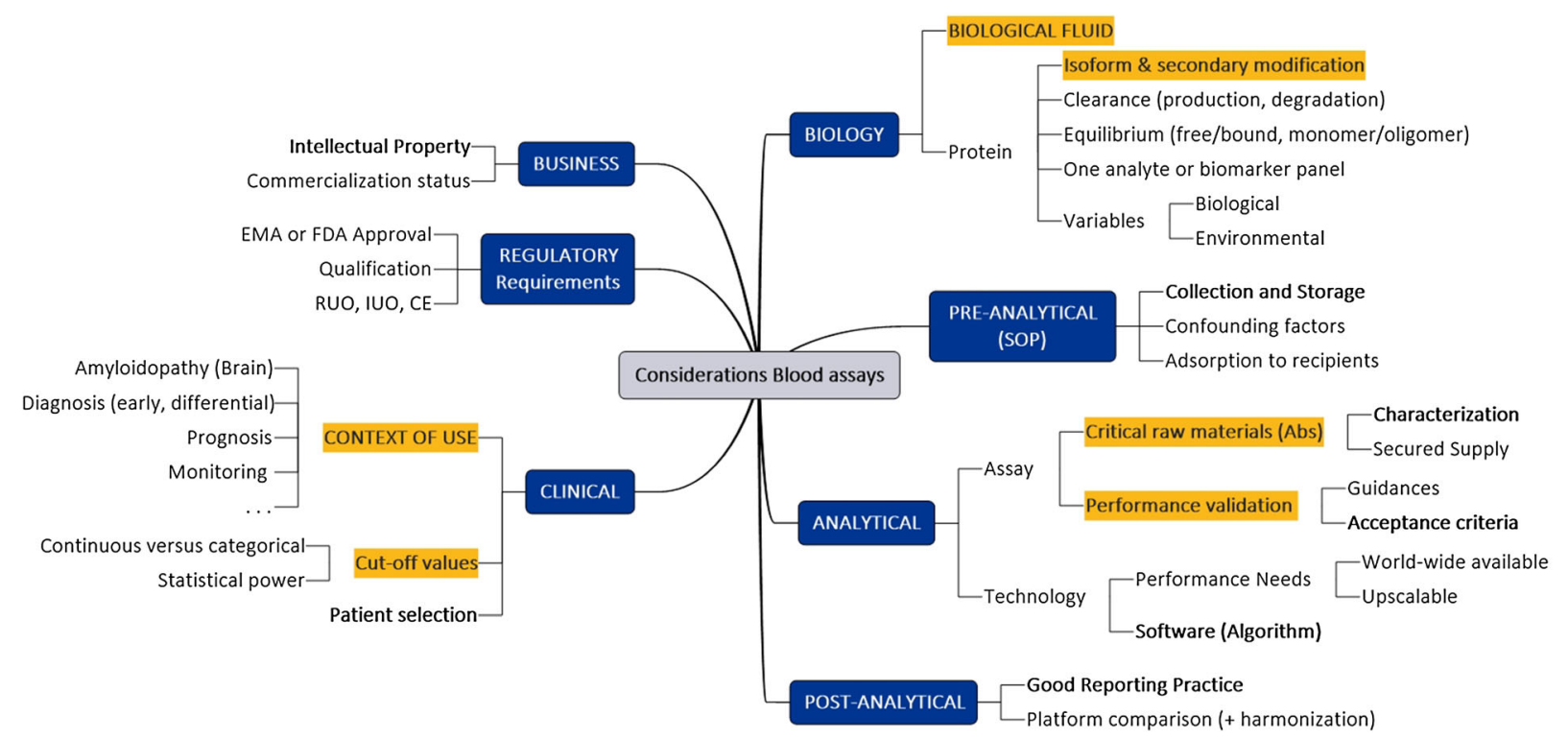

Fig. 1 Factors to be considered during implementation of blood-based biomarker analysis. Analysis of considerations to be taken into account for protein analysis in blood samples, divided in function of the topic (blue boxes). Yellow boxes have a direct relationship with the context of use (COU). Bold/underlined words are considered as more

quantification in cerebrospinal fluid (CSF) of changes in a panel of proteins (A $\beta 42, \mathrm{~A} \beta 40$, total tau, and phosphorylated tau) [27]. In the future, blood-based biomarker panels will offer significant advantages over traditional CSF and neuroimaging biomarkers with respect to invasiveness, accessibility in patient care, (in)direct costs, time and resource utilization, and context of use. Table 1 compares the characteristics of the currently available procedures for $A \beta$ protein analysis.

Potential applications for blood tests are very diverse in the assumption that protein profiles differ between healthy subjects and persons with an ongoing disease process or in function of the progression of the disease. The need is high for protein panels (i) for which the outcome is a reflection of ongoing $A \beta$ formation, (ii) that can accurately reflect changes in this pathology due to a therapeutic intervention, (iii) that can be used for early and/or differential diagnosis with equal accuracy as A $\beta$-PET or CSF analysis, and (iv) that are easy to perform at low cost with limited training requirements. critical for the future development of blood-based biomarker panels. EMA European Medicines Agency, FDA The Food and Drug Administration, IUO for investigation use only, $I V D$ in vitro diagnostics, $R U O$ research use only, $S O P$ standard operating procedure

Many stakeholders are involved in the process of biomarker development (from identification to implementation; from concept to value): key opinion leaders, the diagnostic industry, the pharmaceutical industry, consortia, and patient organizations. All stakeholders need to work closely together in order to identify and accelerate biomarker development for a specific COU $[44,63]$.

\section{THE NEED FOR BLOOD BIOMARKER PANELS FOR AMYLOID AND TAU PATHOLOGY}

Searches for blood-based signatures for AD have been the focus of investigation for several decades [46]. Results were often contradictory, only statistically significant when a high(er) number of subjects was included in the study design, and difficult to replicate in other clinical settings. Inconsistencies in the outcome of the studies can be due to several reasons, such as the biological plausibility of the biomarker in the 
Table 1 Comparison of different aspects relevant for implementation of A $\beta$-PET, CSF, and blood-based analysis methods

\begin{tabular}{|c|c|c|c|}
\hline Topic & A $\beta$-PET imaging & CSF analysis & Blood analysis \\
\hline $\begin{array}{l}\text { Context of use } \\
\text { (COU) }\end{array}$ & $\begin{array}{l}\text { Used in clinical trials as an entry } \\
\text { point for patient stratification with } \\
\text { the aim to identify subjects with } \\
\text { A } \beta \text { load in the brain }[73]\end{array}$ & $\begin{array}{l}\text { More applications: early diagnosis, } \\
\text { differential diagnosis, treatment } \\
\text { follow-up }\end{array}$ & $\begin{array}{l}\text { Multiple applications in the } \\
\text { diagnostic or therapeutic area, } \\
\text { including (pre-) clinical studies } \\
\text { (PK/PD testing) } \\
\text { Biomarkers can be disease-related or } \\
\text { treatment-related, classified by the } \\
\text { BEST biomarker category (Web-1) }\end{array}$ \\
\hline $\begin{array}{l}\text { Clinical } \\
\text { Method } \\
\text { comparison }\end{array}$ & \multicolumn{2}{|c|}{$\begin{array}{l}\text { Both methods have a high clinical accuracy to identify } A \beta \text { load in the brain. } \\
\text { Concordance between results is high, although discrepant results have been } \\
\text { published }\end{array}$} & $\begin{array}{l}\text { Correlation with CSF for some } \\
\text { proteins (e.g., NF-L, A } \beta \text { ratio), not } \\
\text { for other proteins } \\
\text { Comparison needs to be done with } \\
\text { respect to the clinical utility or for } \\
\text { a specific COU } \\
\text { Possibility for use of blood protein } \\
\text { panels in combination with other } \\
\text { diagnostic tools (e.g., CSF) [21] }\end{array}$ \\
\hline $\begin{array}{l}\text { Clinical } \\
\text { Change in } \\
\text { function of } \\
\text { disease process }\end{array}$ & $\begin{array}{l}\text { A } \beta \text {-PET scan differences are } \\
\text { visualized after changes in CSF } \\
\text { biomarker profiles }\end{array}$ & $\begin{array}{l}\text { Changes in concentrations of CSF } \\
\text { proteins are detectable more than } \\
20 \text { years before cognitive } \\
\text { symptoms appear }\end{array}$ & $\begin{array}{l}\text { To be defined, as compared to A } \beta \text { - } \\
\text { PET imaging or CSF analysis } \\
\text { Comparison is dependent on the } \\
\text { COU }\end{array}$ \\
\hline Clinical trials & Used for patient stratification & Exploratory biomarker & Not integrated in trials yet \\
\hline Analytes_number & $\begin{array}{l}\text { One hallmark. } \\
\text { Different outcome in function of the } \\
\text { selected tracer }\end{array}$ & $\begin{array}{l}\text { Several relevant proteins can be } \\
\text { included in the panel (e.g., tau, } A \beta \text {, } \\
\text { NF-L, ...) }\end{array}$ & $\begin{array}{l}\text { A huge number of proteins can be } \\
\text { included in the panel }\end{array}$ \\
\hline & & $\begin{array}{l}\text { Most proteins are detectable with } \\
\text { classical technology platforms }\end{array}$ & $\begin{array}{l}\text { Concentrations are lower than in } \\
\text { CSF (for most of the analytes), but } \\
\text { technologies allow low limit of } \\
\text { detection }\end{array}$ \\
\hline Cost & High cost, limiting repeated measures & $\begin{array}{l}\text { Limited cost/sample } \\
\text { Repeated sampling is possible, but } \\
\text { more difficult }\end{array}$ & $\begin{array}{l}\text { Low cost/sample } \\
\text { Repeated sampling is possible }\end{array}$ \\
\hline Safety & $\begin{array}{l}\text { Exposure to radiation. Problems with } \\
\text { claustrophobia for demented } \\
\text { subject }\end{array}$ & $\begin{array}{l}\text { Lumbar Puncture is perceived as } \\
\text { invasive and with a risk of } 1-5 \% \\
\text { for severe headache problems [59] }\end{array}$ & Safe, routine procedure \\
\hline Instrumentation & $\begin{array}{l}\text { PET scanners: not available } \\
\text { worldwide } \\
\text { Cyclotrons: tracers need to be on-site } \\
\text { within } 1 \mathrm{~h} \text { of preparation } \\
\text { Technology is only available in } \\
\text { specialized centers }\end{array}$ & $\begin{array}{l}\text { Random-access immunoassay } \\
\text { analyzers have been qualified for } \\
\text { accurate and reliable quantification } \\
\text { of CSF proteins [9] }\end{array}$ & $\begin{array}{l}\text { Point-of-care test systems for } \\
\text { multiple protein analysis will } \\
\text { become available soon. Random- } \\
\text { access analyzers are already } \\
\text { available in many labs }\end{array}$ \\
\hline
\end{tabular}


Table 1 continued

\begin{tabular}{|c|c|c|c|}
\hline Topic & A $\beta$-PET imaging & CSF analysis & Blood analysis \\
\hline $\begin{array}{l}\text { Standardization } \\
\text { Training }\end{array}$ & $\begin{array}{l}\text { It needs to be performed } \\
\text { independent of a patient's clinical } \\
\text { feature. Only by readers who } \\
\text { successfully complete a special } \\
\text { training program }\end{array}$ & $\begin{array}{l}\text { CSF-A } \beta 1-42 \text { data can be } \\
\text { harmonized between technology } \\
\text { platforms using CSF-based } \\
\text { certified reference materials [32] } \\
\text { Efforts are ongoing for a worldwide } \\
\text { implementation of a SOP for } \\
\text { collection and storage of CSF. Run- } \\
\text { validation criteria can be } \\
\text { established easily. Each lab } \\
\text { technician, skilled in the art, can } \\
\text { perform these immunoassays }\end{array}$ & $\begin{array}{l}\text { No special training required, except } \\
\text { availability of technicians, skilled } \\
\text { in the art to perform } \\
\text { immunoassays }\end{array}$ \\
\hline $\begin{array}{l}\text { Data } \\
\text { interpretation }\end{array}$ & $\begin{array}{l}\text { Visual interpretation or software. } \\
\text { Flashy outcome }\end{array}$ & $\begin{array}{l}\text { Reader and curve fit algorithms. Obje } \\
\text { difficult. No universal cutoff value }\end{array}$ & $\begin{array}{l}\text { ctive outcome. Interpretation is more } \\
\text { available }\end{array}$ \\
\hline Regulatory & $\begin{array}{l}\text { The FDA approved A } \beta \text {-PET imaging } \\
\text { by visual interpretation ('not } \\
\text { software') to identify subjects with } \\
\text { ongoing amyloidopathy } \\
\text { (= exclusion criterium) [73] }\end{array}$ & $\begin{array}{l}\text { EMA qualified the combined use of } \\
\text { CSF A } \beta \text { and tau proteins as a tool } \\
\text { for patient enrollment in clinical } \\
\text { trials (Web-2) } \\
\text { A letter of support from the FDA } \\
\text { encourages their use in clinical trials } \\
\text { (Web-3). The method must be } \\
\text { used in adjunct to other diagnostic } \\
\text { evaluations. Algorithms based on } \\
\text { CSF proteins, together with } \\
\text { imaging methods, were integrated } \\
\text { into revised criteria for AD } \\
\text { diagnosis [18] and research } \\
\text { proposals for the amyloid/tau/ } \\
\text { neurodegeneration (A/T/N) } \\
\text { classification of AD pathological } \\
\text { processes [27] }\end{array}$ & $\begin{array}{l}\text { No qualification proposals submitted } \\
\text { No regulatory approved assay formats }\end{array}$ \\
\hline
\end{tabular}

Website references: Web-1 https://www.ncbi.nlm.nih.gov/books/NBK326791/; Web-2 https://www.ema.europa.eu/en/documents/ regulatory-procedural-guideline/qualification-opinion-novel-methodologies-predementia-stage-alzheimers-disease-cerebrospinal-fluid_en. pdf; Web-3 https://www.fda.gov/drugs/cder-biomarker-qualification-program/letter-support-los-initiative

$A \beta \beta$-amyloid, $C O U$ context of use, CSF cerebrospinal fluid, EMA the European Medicine Agency, FDA The Food and Drug Administration, NF-L neurofilament light, $P E T$ positron emission tomography, $S O P$ standard operating procedure

context of AD. The outcome of the studies are likely strongly affected by the analytical sensitivity of the methods to quantify the lowabundance brain proteins in blood.
Since people are highly concerned about their quality of life at a later age, they want to take their own decisions based on objective, evidence-based methods that can precisely indicate their risk for cognitive decline in the 
future. There is an urgent need for a blood test for $\mathrm{AD}$ that can function in a comparable way as cholesterol measurements as an indicator for possible cardiovascular diseases. In general, blood immunoassays are easy to implement in a routine clinical environment and are cost-effective. The turnaround time is short. They could become a good tool for prescreening purposes in subjects with cognitive decline, followed later by confirmation or verification of the diagnosis using more labor-intensive mass spectrometry blood plasma analysis methods, CSF analysis, or A $\beta$-PET imaging. A more final diagnosis or treatment decision can be provided after the second line of testing.

In an ideal situation, the blood biomarker must reflect ongoing brain pathology and correlate with CSF protein data. Moreover, in view of the involvement of multiple pathologies in $\mathrm{AD}$, a multi-protein approach with fluid-based immunoassays is the most obvious choice. A negative protein profile in blood would indicate the presence of sparse or no neuritic plaques or tangles; it could be inconsistent with a neuropathological diagnosis of $\mathrm{AD}$ at the time of image acquisition, and could reduce the likelihood that a patient's cognitive impairment is due to AD. False negatives need to be excluded as much as possible. A positive protein profile in blood could indicate the presence of moderate to frequent amyloid neuritic plaques, tangles, and other relevant pathologies. The number of false positives also needs to be as minimum as possible in order to avoid unnecessary anxiety in patients.

For clinical trials, biomarkers are needed as tools need to reflect the disease modification in the long preclinical stage. Reliable blood tests have the potential to directly affect the time and cost of the drug-development process by delivery of objective tools to measure quantitatively mechanistic effects or treatment efficiencies (go, no-go decisions) or to support identification of individuals likely to respond to a given drug (predictive outcome measures), or to experience adverse drug effects (safety outcome measures). They would be able to monitor improvements in clinical outcome, such as cognition and daily living activities of the affected subjects.

\section{A STRATEGY TO DEVELOP CLINICALLY VALUABLE BLOOD PROTEIN PANELS WITH A FOCUS ON AB AND TAU QUANTIFICATION}

The pathophysiology of $\mathrm{AD}$ was explored in the past by several approaches, such as by focusing on biological candidates obtained from prevailing pathogenetic hypotheses (mono-mechanistic approach) or by a discovery approach, profiling protein differences between pathological and healthy states (proteomics approach) $[5,40]$. Pre-analytical standardization has not been widely integrated in assay development for blood proteins. The abovementioned methods do not necessarily focus on the presence of a free (non-protein bound) analyte or on a specific protein isoform. The hypothesis-based methods limit the possibility to identify proteins that capture the full pathophysiological complexity of $\mathrm{AD}$ across stages from upstream to downstream mechanisms. Another key point in biomarker identification efforts is the availability of (clinical) patient samples that are closely related to a specific COU. For example, studies usually start with comparing biomarker concentrations in biological fluids between defined AD patients and healthy controls, while studies which are aimed to estimate the progression rate of the disease or cognitive decline during different phases of the disease process require a different study design.

Very importantly, protein concentrations in plasma are almost 100-fold higher than in CSF, but clinically relevant proteins (e.g., tau, $A \beta$ isoforms) will only be present in blood in very low amounts [4], pointing to the need to switch from a classical ELISA to technology platforms with a low analytical sensitivity for their analysis. The source of the protein in a specific biological fluid, as well as its presence in nonblood sample types (e.g., tears, saliva), complicates the story further.

Neurodegenerative diseases are caused by misfolding of native proteins into oligomers, protofibrils, and fibrils. Aggregation of $A \beta$ is a central feature of many neurodegenerative diseases, but not limited to $\mathrm{AD}[38,43]$. Circulating $A \beta$ is pathophysiologically important since $A \beta$ 
can move from the brain to the peripheral circulation through the blood-brain barrier [16] and from the peripheral circulation to the brain [15]. Notwithstanding the many clinical trial failures [13], impaired processing of $A \beta$ from the amyloid precursor protein (APP) by secretase enzymes, the secondary modification of $A \beta$ (truncation at amino (N)- or carboxy (C)-terminus [57], isomerization, oxidation, and oligomerization), and an impaired clearance of $\mathrm{A} \beta$ from the brain or the periphery are still considered as major targets for therapeutic trials. They are important triggers for an initiation of the pathology.

Nowadays, there is a shift from $A \beta$ therapies to approaches which target the tau protein. For tau blood assays, the availability of highly sensitive, microfluidics-based technologies has allowed the field to quantify tau proteins in blood using specific pairs of monoclonal antibodies (mAbs) [37, 75]. However, development of immunoassays using mAbs against phosphotau (e.g., ptau181) [39] or using combinations of mAbs with different epitopes (e.g., BT2, tau12) [12] revealed that it is possible to reduce the overlap in tau concentrations between a healthy control and $\mathrm{AD}$ and to obtain a better correlation between CSF and plasma levels. The latter will result in an improved diagnostic accuracy or relationship with the tau pathology. So, it will be essential to further define the specificity of tau antibodies and to establish their relation to tau pathology in order to advance our current understanding of plasma tau measurements with respect to the pathophysiology of AD.

Several isoforms ${ }^{3}$ of the same protein might be present in blood, or the protein can have a secondary modification in blood which is not identical to its modification in brain or CSF. The equilibrium between monomeric or oligomeric forms of the protein or the degree of matrix interference (e.g., binding to fluid proteins or cells, presence of heterophilic antibodies or auto-antibodies) can have an influence on their

\footnotetext{
${ }^{3}$ A protein isoform is one of a number of different structurally similar proteins that are created as the result of alternative splicing or from similar genes formed from a copied gene and differentiated as the result of evolution.
}

analysis. Pre-analytical processing can potentially result in an enrichment of a specific isoform which is not necessarily the isoform with the highest clinical value.

The complex matrix of blood makes development of highly qualified blood assays with clinical value much more difficult than for CSF. It requires a very extensive standardization of the test method at the level of the assay, the lab, and the sample, including generation of SOPs for collection and storage of biological fluids. Quantification of $A \beta$ proteins in non-CSF or blood samples has long been considered as of limited clinical value for the community [10], although, even at that time and using classical colorimetric immunoassays [67] or the XMAP technology [23, 34], they have shown already promise to identify patients at risk for cognitive decline. The revival of the idea of using plasma $\mathrm{A} \beta$ as an alternative for $\mathrm{A} \beta$-PET imaging became much more concrete with the emergence of improved ELISA assay designs [51], highly sensitive technology platforms $[28,48,68]$, and the use of immunoprecipitation followed by mass spectrometry $[41,47,56]$. Nowadays, there is an extended know-how on how to standardize assays based on knowledge generated in the development of CSF AD biomarkers and the availability of tissues or biological fluids from well-characterized biobanks. Other factors facilitating blood-based biomarker development is an improvement of study designs (e.g., harmonization study designs towards a specifically defined COU, such as the concordance with $A \beta$ PET imaging), the availability of a Food and Drug administration (FDA)-approved reference method (A $\beta$-PET imaging with visual interpretation), a better selection and characterization of subjects (CSF biomarker profiles, A $\beta$-PET imaging) accompanied with the awareness of the need for SOPs for sample collection and storage, the use of larger sample sizes, and the inclusion of qualification and validation cohorts.

One example of the above considerations is the recent data on quantification of the A $\beta 1-42 /$ A $\beta 1-40$ ratio in EDTA plasma, which is directly related to ongoing pathological processes in the brain. A $\beta$-PET imaging determines plaque load in the brain [73]. The ratio of plasma $A \beta 1-42 /$ 
$\mathrm{A} \beta 1-40$ is not only concordant with $\mathrm{A} \beta$-PET, but also with CSF [68]. In addition, since the CSF A $\beta 1-42 / A \beta 1-40$ ratio is correlated with CSF-Ptau181P [72], it suggests that plasma tau and the ratio of $A \beta 1-42 / A \beta 1-40$ might become useful in the future for differential diagnosis or to predict disease progression.

A limitation of the current design of the immunoassays is that it seems to be more difficult than expected to obtain an identical diagnostic accuracy for the ratio of $A \beta 1-42 / A \beta 1$ 40 as obtained with immunoprecipitation mass spectrometry (IP-MS), unless some changes in the assay design are introduced, such as production of assays for several other $A \beta$ isoforms. For $A \beta$, one has to consider the presence of multiple isoforms in blood. Masters et al. [36] described already in 1985 that $\mathrm{A} \beta$ proteins sequenced from parenchymal plaques have ragged $\mathrm{NH}_{2}$ termini. In addition, a study using mass spectrometry revealed that several $\mathrm{N}$ - or C-terminal truncated $A \beta$ peptides are present in platelets [31]. N-terminal truncated amyloid isoforms predominate in the insoluble material, while the C-terminal truncations are segregated into soluble aggregates [70]. Post-translational modifications include, besides others, pyroglutamate (at position 3 or 11), truncation at $\mathrm{A} \beta 4$, and oxidation of methionine [58, 74].

According to our knowledge, selectivity ${ }^{4}$ and specificity experiments with a major focus on quantification of such specific $A \beta$ isoforms have not been documented yet for the currently available assay formats, limiting the interpretation of the outcome of the studies and potential value for blood $A \beta$. It is conceivable that the clinical value of plasma amyloid analysis will reflect better the full complexity of $\mathrm{AD}$ if the panel is extended, after a critical evaluation of the improved performance, by using the ratios of $A \beta 42$ to other $A \beta$ isoforms (e.g., $A \beta 38$ [26], $A \beta 34$ [35], $A \beta-3$ [41]) or by using the ratio $A \beta 1 /$

\footnotetext{
4 Selectivity: extent to which the method can determine a particular compound in the analyzed matrices without interference from matrix components. Specificity: ability of the method to assess, unequivocally, the analyte in the presence of other components that are expected to be present (e.g., impurities, degradation products, matrix components, etc.). https://www.fda.gov/regulato ry-information/search-fda-guidance-documents/bioana lytical-method-validation-guidance-industry.
}

$\mathrm{A} \beta \mathrm{N}$, as documented previously in CSF studies [64]. A $\beta$ must be combined in the panel with proteins that are correlated to other hallmarks of the disease, such as apolipoprotein E, (phospho)tau [21], neurofilament light, $\beta$ secretase 1 (BACE1) protein [69], soluble triggering receptor expressed on myeloid cells 2 (sTREM2), or inflammation markers [40]. Documentation of the added value of multiplexing of these protein combinations for a specific COU will have to be studied in large cohorts with biobanks from different worldwide consortia.

\section{TECHNOLOGICAL CONSIDERATIONS FOR ASSAY DEVELOPMENT AND CRITICAL RAW MATERIALS FOR AB AND TAU QUANTIFICATION IN BLOOD}

\section{Assay Validation}

At present, no blood-based biomarker panel has been validated for clinical use or as part of clinical trials. A recent guidance document ${ }^{5}$ did mention that clinical and analytical validation for a specific COU are distinct processes, but closely dependent on one another (summarized in Fig. 2). The document describes that a reliable test should be used to measure the biomarker before biomarker measurement cutoff values can be established and that cutoff values should be defined before the biomarker test can be analytically validated. This relationship should be supported by statistical analyses (degree and certainty of association between a biomarker and an outcome of interest) and should come from multiple independent data sources. Sample-size requirements should be calculated based on statistical criteria to ensure adequate power to assess clinically relevant associations between the biomarker and the outcome of interest with reasonable dispersion. Sample-size considerations could be based on a single study or multiple studies considered in aggregate. Depending on the COU, cutoff

\footnotetext{
5 https://www.fda.gov/regulatory-information/searchfda-guidance-documents/biomarker-qualification-eviden tiary-framework.
} 


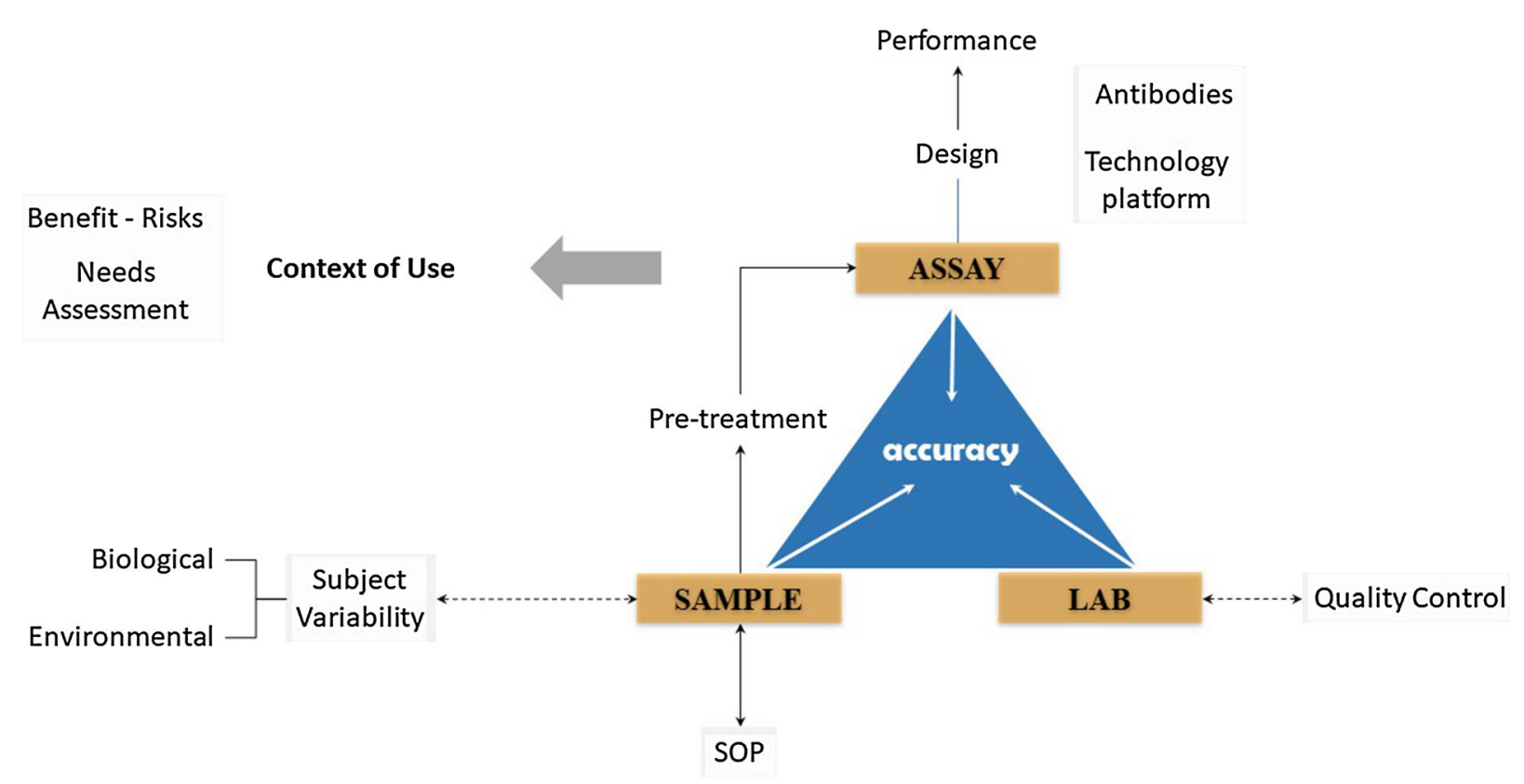

CLINICAL VALIDATION

Fig. 2 Precision qualified assays (PQAs). The general concept of assay validation. Clinical and analytical validation for a specific COU are distinct processes, but closely dependent on one another. PQAs will provide a solution by better combining clearly defined analytical performance requirements of an assay (e.g., selectivity, specificity,

values or combinations of proteins in the algorithm might differ considerably (see footnote $5)$.

Analytical validation must establish that the analytical performance characteristics of a biomarker test are acceptable for the proposed COU. Validation data and details on the source and characteristics of critical raw materials (Abs, calibrators) are often missing when introducing novel assays in the field. Harmonization of results between assay formats developed on different technology platforms is required in order to understand the clinical relevance of the findings better.

At the analytical level, we would like to introduce a new term: precision qualified assays (PQAs). PQAs will provide a solution by the obligation of combining clearly defined analytical performance requirements of an assay (e.g., selectivity, specificity, accuracy, linearity/parallelism) with the observed effects in patient

\section{ANALYTICAL VALIDATION}

accuracy, linearity/parallelism) with the observed effects in a patient. PQAs means that results of the analytical performance studies are interpreted in view of their effects for individual patient management. SOP standard operating procedure

samples. In principle, results of analytical performance studies have to be interpreted in view of their effects for individual patient management. This requires a high(er) level of standardization of biomarker assays as usually done. This means that validation and standardization is not only performed at the level of the lab, the sample, and the assay, but must also address biological variation or biological differences in a specific COU. Analytical validation must establish that the analytical performance characteristics of a biomarker test are acceptable for the proposed COU. In addition, parameters that interfere with the precision and accuracy ${ }^{6}$ of the analysis should be identified (e.g., use of other drugs that may interfere with the assay in a treatment response monitoring $\mathrm{COU}$ ), and

\footnotetext{
${ }^{6}$ Accuracy: The degree of closeness of the determined value to the nominal or known true value under prescribed conditions.
} 
strategies to minimize bias should be described. The use of published guidance documents can help to make the experimental protocols for each analytical performance characteristic much more robust. They will define what is needed in function of the phase of the project ${ }^{7,8}$. Efforts or workload for standardization can differ in function of the phase of the project (see footnote 8 ), the COU, or the regulatory status of the test methods [laboratory-developed tests vs. research use only vs. in vitro diagnostics (IVDs)]. Uniform reporting of studies with fluid biomarkers, as proposed by Gnananpavan et al. [22], will accelerate acceptance for selected biomarkers in the clinical environment.

Clinical validation must provide evidence for a relation between the pathological process and a COU. Clinical validation must establish that a biomarker's relationship with the outcome of interest is acceptable for the proposed COU.

At this point in time, it is easier in a clinical lab environment to generate a clinically meaningful outcome using immunoassays (e.g., colorimetric, chemiluminescence) or single molecule analyzers, as compared to mass spectrometry.

\section{Critical Raw Materials}

Hundreds of mAbs or polyclonal antibodies (pAbs) were developed against the $A \beta$ and tau protein, but only a few of them have been characterized in extenso with respect to the protein isoform that is measured in a biological sample when integrated into immunoassays or when used for immunoprecipitation in combination with mass spectrometry. Antibody requirements might differ in function of method (chromatographic assays, ligand-binding assays) [54] and in function of the development phase of the assay. Details on mAbs included in an assay design or information on $\mathrm{mAb}$ characteristics [e.g., affinity, epitopes, selectivity (e.g., binding to other proteins or matrix interferences), specificity, long-term

\footnotetext{
7 https://www.fda.gov/media/70858/download.

8 https://c-path.org/wp-content/uploads/2019/06/Evid Consid-WhitePaper-AnalyticalSectionV20190621.pdf.
}

stability, or lot-to-lot variability] is often missing, although it is considered as essential to understand the contribution of the specificity of each selected $\mathrm{Ab}$ for the generation of clinical valuable data.

Here, we provide an example for the importance of comprehensive antibody characterization for assay development. The most commonly used mAbs for $A \beta$ quantification, $6 \mathrm{E} 10$ and 4G8, were produced more than 25 years ago [50]. Baghallab et al. [6] more recently performed immunoselection of random sequences from a phage display library, followed by deep sequencing, to document epitopes of mAbs $6 \mathrm{E} 10$ and $4 \mathrm{G} 8$ as $4-10$ and 18-23, respectively. Both mAbs not only react with the monomeric form of the protein, but react also with amyloid aggregates in a conformation-dependent fashion. Immunoreactivity in samples is obtained under specific conditions and aggregation times [24]. Furthermore, 4G8 recognizes a generic sequence-independent epitope associated with $\alpha$-synuclein and islet amyloid polypeptide amyloid fibrils [25]. So, recognition of a linear sequence in a protein is not necessarily a reliable indicator of $\mathrm{mAb}$ specificity. Although these mAbs have helped the field in understanding the pathology of $\mathrm{AD}$, the findings described above compromise in part some of the published findings obtained with immunoassays in which 6E10 or 4G8 were included in the assay design. It strengthens our point that extensive documentation of characteristics of $\mathrm{mAbs}$ is required in order to be able to have a correct interpretation of data obtained from observational studies or clinical trials.

Assay specificity towards $A \beta$ isoforms is the resultant of the combined specificity of the mAbs included in the assay design. It has clinical and biological relevance since the pathology of $\mathrm{AD}$ and its change over time is determined by changes in concentrations of $A \beta$ proteins modified at the $\mathrm{C}$ - and N-terminus after processing from the APP precursor protein [57]. We believe that assays which are developed on technology platforms with only one antibody, $\mathrm{mAb}$ or $\mathrm{pAb}$, cannot generate specificity towards a specific analyte, notwithstanding available clinical data. Similarly, if one uses in the assay design a mAb with an epitope in the 
mid-region of $\mathrm{A} \beta$ and not against the free- $\mathrm{N}$ terminus (e.g., WO2, 6E10, 4G8), then a mixture of proteins modified at the N-terminus will be quantified. So, one will never know the relative contribution of one isoform as compared to another [64].

We see it as an advantage for the field and for future harmonization of $A \beta$ results between technology platforms if vendors are willing to omit the use of pAbs in the assay design and select only well-characterized mAbs with high purity (low level of degradation, limited amount of aggregation). This is already the case for mAbs 21F12, 2G3, and 3D6, described by Johnson-Wood et al. [29], which are present in colorimetric ELISAs from different vendors, on random-access analyzers, and on single molecule array (Simoa) assays.

\section{Standard Operating Procedures}

Each step in the flow from blood sample collection to processing and storage (either longterm for biobanking or intermediate for routine analysis) before analysis must be evaluated in extenso with well-designed study protocols and enough statistical power to generate an evidence-based consensus on a SOP [62, 65, 71]. An overview of steps to be investigated is shown in Fig. 3. Very early in the development process, one needs to obtain an understanding of the biological and environmental variability that can affect the analyte concentrations in a sample, the mechanism of clearance and degradation in the blood compartment, the presence of confounding factors, and the possible correlation with blood-brain-barrier deficits.

We recommend the combination of several (pre-)analytical factors in one experimental

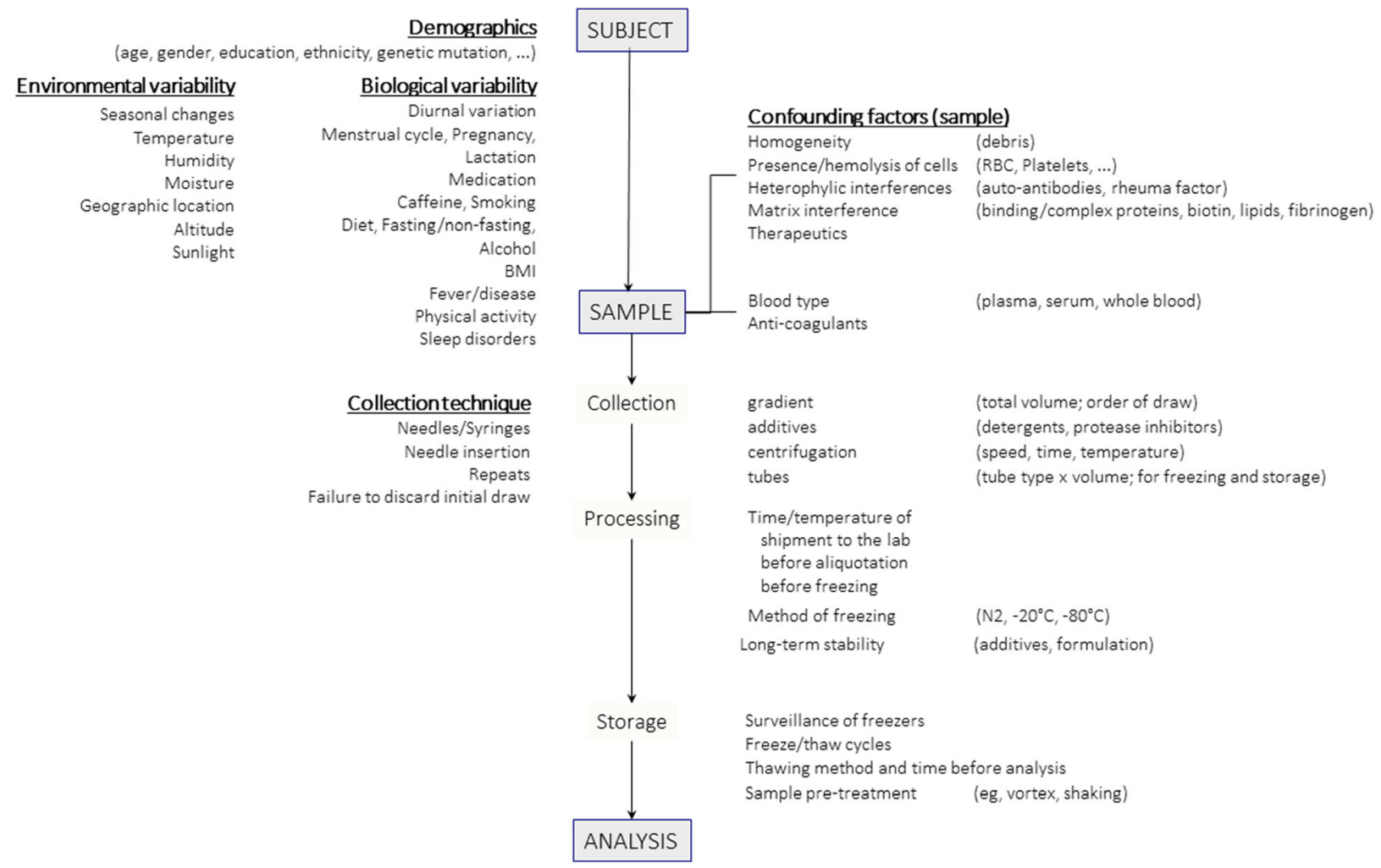

Fig. 3 Overview of pre-analytical factors that may affect the biomarker concentrations in blood samples. An documented as part of the generation of procedures for collection of blood samples for protein quantification in blood samples. $N 2$ liquid nitrogen, $R B C$ red blood cells 
design, so that interactions between parameters can be defined more effectively (e.g., sample volume and freezing). SOPs need to be prepared for each individual protein that is included in the biomarker panel or algorithm. As documented for amyloid analysis in CSF [66], it is likely better to focus immediately on using the ratio of the proteins (e.g., $A \beta 42 / A \beta 40$ as compared to $A \beta 42$ alone) when performing detailed evaluations of the robustness of collection procedures, if these will be the ultimate markers for use in practice. Some steps in the process might be more important for one analyte as compared to other proteins or might be more critical for a specific technology platform as compared to others. This might ultimately lead to consensus statements in which compromises have to be made before a universal and unified SOP is available to the field.

With the recent technology improvements, it becomes technically feasible to measure $A \beta$ in several blood sample types (e.g., serum, EDTA plasma). It can be foreseen that each sample type or modification of sample processing can ultimately result in a different clinical outcome. In the past, clear differences in $A \beta$ concentrations were observed for $A \beta 1-42$ and $A \beta 1-40$ in function of the sample type using the Luminex technology [33]. Recently, smaller differences in $\mathrm{A} \beta$ concentrations between sample types have been reported for assays using the Elecsys system [53] or the Simoa technology (Stoops et al. Abstract AAIC [61].

The few studies focusing on pre-analytical stability of $A \beta 1-42$ in plasma have suggested that stability of $A \beta$ is likely not as good as in CSF. A very thorough and critical review of the importance of each step in the pre-analytical procedures is required. The biological half-life of $A \beta$ isoforms in plasma was found to be approximately $3 \mathrm{~h}$, which is considerably faster than in CSF. A $\beta 38$ labeling kinetics peaked earlier and higher than $A \beta 40$ and $A \beta 42$, indicating a faster turnover rate due to aggregation and deposition. A faster fractional turnover of $A \beta 42$ relative to $A \beta 40$ was observed in $A \beta$-positive participants [47].

Another aspect to be considered for plasma $\mathrm{A} \beta$ analysis is its binding to several proteins in the blood compartment, including but not limited to albumin, transferrin, lipoprotein receptor-related protein-1 [8] or auto-antibodies [17]. A $\beta$ can also directly interact with proteins involved in the neurodegeneration process, such as apolipoproteins or $\alpha$-synuclein, producing hybrid oligomers in red blood cells of healthy subjects and Parkinson's disease [3, 14].

In general, blood cell types are considered as confounding factor for blood protein analysis. Hemolytic samples or samples with a high(er) concentration of hemoglobin, a surrogate marker for lysis of red blood cell, need to be excluded for further analysis. Red blood cells are involved in the accumulation and clearance of proteins. $A \beta$ dose-dependently activated serum complement and complement-opsonized $\mathrm{A} \beta$ is captured by erythrocytes via a complement receptor 1 [11]. Several AD-related biomarkers (e.g., $A \beta$, tau, synuclein) might be present in red blood cells [7, 49], while platelets have been shown to contribute considerably to the total pool of $A \beta$ in the periphery [45]. Immunoassay analysis or size-exclusion fast protein liquid chromatography (FPLC) and reverse-phase high-performance liquid chromatography (HPLC) revealed the presence of $A \beta 40$ and very low levels of $A \beta 42$ in (in)activated platelets, representing $2-3 \%$ of the total amount of $A \beta$ in the blood [52]. The exact biological relevance is, however, not yet clear. For example, prostaglandin E1 is added to EDTA plasma in the Australian imaging, biomarkers and lifestyle (AIBL) cohort for inhibition purposes [20], while on the other hand, [45] this product is used, in combination with others, to stimulate the release of $A \beta$ from the platelets. For plasma tau, more studies are required to determine the importance of pre-analytical variables. As such, the preparation protocols for samples, which is affected in part by centrifugation speeds or the stimulation and inhibition of the release of proteins from the platelets, can directly affect concentrations of a specific protein in blood.

\section{GENERAL CONCLUSIONS}

In the near future, more information will become available on the importance of $\mathrm{mAb}$ selection in the assay design, the requirements 
for more extended analytical performance validation, and effects of harmonization of SOPs for collection and storage of biological fluids on the clinical outcome of each test method.

Consortia and regulatory entities have the difficult task to gather all historically available data from research teams or pharma, and to define relevant experiments to supplement these data. Initiatives from the Alzheimer's Association and the Foundation for the National Institutes of Health are already ongoing to gather all relevant historical data and to define the need for additional experiments. A more detailed reporting practice will be required on analytical performance characteristics of assays, including but not limited to the characteristics of mAbs that are used in assays. It will help the field to better understand how changes in analyte levels are related to the AD pathological processes, as well as on how to use it to monitor disease progression and severity.

In conclusion, everything is in place to bring blood biomarker testing to a higher level, but mistakes from the past need to be considered in order to shorten the time for worldwide integration of the blood assays. Immunoassays have the advantage of combining biomarkers relevant to the disease process, they are easy to implement in larger studies, and will help to fully understand and document the clinical relevance of combinations of analytes for a specific COU.

\section{ACKNOWLEDGEMENTS}

Funding. No funding or sponsorship was received for publication of this article.

Authorship. All named authors meet the International Committee of Medical Journal Editors (ICMJE) criteria for authorship for this article, take responsibility for the integrity of the work as a whole, and have given their approval for this version to be published.

Disclosures. Hugo Marcel Vanderstichele is a founder of Biomarkable bvba and co-founder of ADx NeuroSciences NV. Eugeen Vanmechelen is a founder for Key4AD and a co-founder of ADx NeuroSciences NV. Charlotte E Teunissen has nothing to disclose.

Compliance with Ethics Guidelines. This article is based on previously conducted studies and does not contain any studies with human participants or animals performed by any of the authors.

Open Access. This article is distributed under the terms of the Creative Commons Attribution-NonCommercial 4.0 International License (http://creativecommons.org/licenses/ by-nc/4.0/), which permits any noncommercial use, distribution, and reproduction in any medium, provided you give appropriate credit to the original author(s) and the source, provide a link to the Creative Commons license, and indicate if changes were made.

\section{REFERENCES}

1. Alzheimer's Association Report. Alzheimer's disease facts and figures. Alzheimer's Dement. 2018;2018(14):367-429.

2. Alzheimer A. Über einen eigenartigen schweren Erkrankungsproze $\beta$ der Hirnrinde. Neurol Central. 1906;25:1134.

3. Andersen AD, Binzer M, Stenager E, Gramsbergen JB. Cerebrospinal fluid biomarkers for Parkinson's disease-a systematic review. Acta Neurol Scand. 2017;135:34-56.

4. Anderson NL, Anderson NG. The human plasma proteome: history, character, and diagnostic prospects. Mol Cell Proteomics. 2002;1:845-67.

5. Ashton NJ, Nevado-Holgado AJ, Barber IS, Lynham S, Gupta V, Chatterjee P, Goozee K, Hone E, Pedrini S, Blennow K, Schöll M, Zetterberg H, Ellis KA, Bush AI, Rowe CC, Villemagne VL, Ames D, Masters CL, Aarsland D, Powell J, Lovestone S, Martins R, Hye A. A plasma protein classifier for predicting amyloid burden for preclinical Alzheimer's disease. Sci Adv. 2019;5:eaau7220.

6. Baghallab I, Reyes-Ruiz JM, Abulnaja K, Huwait E, Glabe C. Epitomic characterization of the specificity of the anti-Amyloid $A \beta$ monoclonal antibodies 6E10 and 4G8. J Alzheimers Dis. 2018;66:1235-44. 
7. Barbour R, Kling K, Anderson JP, Banducci K, Cole T, Diep L, Fox M, Goldstein JM, Soriano F, Seubert $\mathrm{P}$, Chilcote TJ. Red blood cells are the major source of alpha-synuclein in blood. Neurodegener Dis. 2008;5:55-9.

8. Bell RD, Sagare AP, Friedman AE, Bedi GS, Holtzman DM, Deane R, Zlokovic BV. Transport pathways for clearance of human Alzheimer's amyloid beta-peptide and apolipoproteins $\mathrm{E}$ and $\mathrm{J}$ in the mouse central nervous system. J Cereb Blood Flow Metab. 2007;27:909-18.

9. Bittner $\mathrm{T}$, Zetterberg $\mathrm{H}$, Teunissen $\mathrm{CE}$, Ostlund RE Jr, Militello M, Andreasson U, Hubeek I, Gibson D, Chu DC, Eichenlaub U, Heiss P, Kobold U, Leinenbach A, Madin K, Manuilova E, Rabe C, Blennow K. Technical performance of a novel, fully automated electrochemiluminescence immunoassay for the quantitation of $\beta$-amyloid (1-42) in human cerebrospinal fluid. Alzheimers Dement. 2016;12:517-26.

10. Blennow $\mathrm{K}$, Hampel $\mathrm{H}$, Weiner $\mathrm{M}$, Zetterberg $\mathrm{H}$. Cerebrospinal fluid and plasma biomarkers in Alzheimer disease. Nat Rev Neurol. 2010;6:131-44.

11. Brubaker WD, Crane A, Johansson JU, Yen K, Garfinkel K, Mastroeni D, Asok P, Bradt B, Sabbagh M, Wallace TL, Glavis-Bloom C, Tenner AJ, Rogers J. Peripheral complement interactions with amyloid $\beta$ peptide: erythrocyte clearance mechanisms. Alzheimers Dement. 2017;13:1397-409.

12. Chen Z, Mengel D, Keshavan A, Rissman RA, Billinton A, Perkinton M, Percival-Alwyn J, Schultz A, Properzi M, Johnson K, Selkoe DJ, Sperling RA, Patel P, Zetterberg H, Galasko D, Schott JM, Walsh DM. Learnings about the complexity of extracellular tau aid development of a blood-based screen for Alzheimer's disease. Alzheimers Dement. 2019;15: 487-96.

13. Cummings J, Lee G, Ritter A, Sabbagh M, Zhong K. Alzheimer's disease drug development pipeline: 2019. Alzheimers Dement Trans Res Clin Interv. 2019;5:272-93.

14. Daniele S, Pietrobono D, Fusi J, Iofrida C, Chico L, Petrozzi L, Gerfo AL, Baldacci F, Galetta F, Siciliano G, Bonuccelli U, Santoro G, Trincavelli ML, Franzoni F, Martini C. $\alpha$-Synuclein aggregates with $\beta$ amyloid or tau in human red blood cells: correlation with antioxidant capability and physical exercise in human healthy subjects. Mol Neurobiol. 2018;55:2653-75.

15. Deane R, Du Yan S, Submamaryan RK, LaRue B, Jovanovic S, Hogg E, Welch D, Manness L, Lin C, Yu J, Zhu H, Ghiso J, Frangione B, Stern A, Schmidt AM, Armstrong DL, Arnold B, Liliensiek B, Nawroth P, Hofman F, Kindy M, Stern D, Zlokovic B. RAGE mediates amyloid-beta peptide transport across the blood-brain barrier and accumulation in brain. Nat Med. 2003;9:907-13.

16. DeMattos RB, Bales KR, Cummins DJ, Dodart JC, Paul SM, Holtzman DM. Peripheral anti-A beta antibody alters CNS and plasma A beta clearance and decreases brain A beta burden in a mouse model of Alzheimer's disease. Proc Natl Acad Sci USA. 2001;98:8850-5.

17. DeMarshall CA, Nagele EP, Sarkar A, Acharya NK, Godsey G, Goldwaser EL, Kosciuk M, Thayasivam U, Han M, Belinka B, Nagele RG, Alzheimer's Disease Neuroimaging Initiative. Detection of Alzheimer's disease at mild cognitive impairment and disease progression using autoantibodies as bloodbased biomarkers. Alzheimers Dement (Amst). 2016;3:51-62.

18. Dubois B, Feldman HH, Jacova C, et al. Advancing research diagnostic criteria for Alzheimer's disease: the IWG-2 criteria. Lancet Neurol. 2014;13:614-29.

19. Dubois B, Hampel H, Feldman HH, Scheltens P, Aisen P, Andrieu S, Bakardjian H, Benali H, Bertram L, Blennow K, Broich K, Cavedo E, Crutch S, Dartigues J-F, Duyckaerts C, Epelbaum S, Frisoni GB, Gauthier S, Genthon R, Gouw AA, Habert M-O, Holtzman DM, Kivipelto M, Lista S, Molinuevo JL, O'Bryant SE, Rabinovici GD, Rowe C, Salloway S, Schneider LS, Sperling R, Teichmann M, Carrillo MC, Cummings J, Jack CR Jr, From the Proceedings of the Meeting of the International Working Group (IWG) and the American Alzheimer's Association on "The Preclinical State of AD". Preclinical Alzheimer's disease: definition, natural history, and diagnostic criteria. Alzheimers Dement. 2016;12: 292-323.

20. Ellis KA, Bush AI, Darby D, De Fazio D, Foster J, Hudson P, Lautenschlager NT, Lenzo N, Martins RN, Maruff P, Masters C, Milner A, Pike K, Rowe C, Savage G, Szoeke C, Taddei K, Villemagne V, Woodward M, Ames D, AIBL Research Group. The Australian Imaging, Biomarkers and Lifestyle (AIBL) study of aging: methodology and baseline characteristics of 1112 individuals recruited for a longitudinal study of Alzheimer's disease. Int Psychogeriatr. 2009;21:672-87.

21. Fossati S, Cejudo JR, Debure L, Pirraglia E, Sone JY, Li Y, Chen J, Butler T, Zetterberg H, Blennow K, de Leon MJ. Plasma tau complements CSF tau and P-tau in the diagnosis of Alzheimer's disease. Alzheimers Dement (Amst). 2019;11:483-92.

22. Gnanapavan S, Hegen $H$, Khalil $M$, Hemmer B, Franciotta D, Hughes S, Hintzen R, Jeromin A, Havrdova E, Tumani H, Bertolotto A, Comabella M, Frederiksen J, Álvarez-Cermeño JC, Villar L, Galimberti D, Myhr K-M, Dujmovic I, Fazekas F, Ionete 
C, Menge T, Kuhle J, Keir G, Deisenhammer F, Teunissen C, Giovannoni G. Guidelines for uniform reporting of body fluid biomarker studies in neurologic disorders. Neurology. 2014;83:1210-6.

23. Hansson O, Zetterberg H, Vanmechelen E, Vanderstichele $\mathrm{H}$, Andreasson $\mathrm{U}$, Londos E, Wallin A, Minthon L, Blennow K. Evaluation of plasma $A \beta(40)$ and $A \beta(42)$ as predictors of conversion to Alzheimer's disease in patients with mild cognitive impairment. Neurobiol Aging. 2010;31:357-67.

24. Hatami A, Albay R III, Monjazeb S, Milton S, Glabe C. Monoclonal antibodies against A $\beta 42$ fibrils distinguish multiple aggregation state polymorphisms in vitro and in Alzheimer disease brain. J Biol Chem. 2014;289:32131-43.

25. Hatami A, Monjazeb S, Glabe C. The anti-amyloid- $\beta$ monoclonal antibody 4G8 recognizes a generic sequence-independent epitope associated with $\alpha$ synuclein and islet amyloid polypeptide amyloid fibrils. J Alzheimers Dis. 2016;50:517-25.

26. Hilal S, Ikram MA, Verbeek MM, Franco OH, Stoops E, Vanderstichele $H$, Niessen WJ, Vernooij MW. C-reactive protein, plasma amyloid- $\beta$ levels, and their interaction with magnetic resonance imaging markers. Stroke. 2018;49:2692-8.

27. Jack CR, Bennett DA, Blennow K, Carrillo MC, Dunn B, Haeberlein SB, NIA-AA, et al. Research framework: toward a biological definition of Alzheimer's disease. Alzheimers Dement. 2018;14: 535-62.

28. Janelidze S, Stomrud E, Palmqvist S, Zetterberg H, van Westen D, Jeromin A, Song L, Hanlon D, Tan Hehir CA, Baker D, Blennow K, Hansson O, et al. Plasma $\beta$-amyloid in Alzheimer's disease and vascular disease. Sci Rep. 2016;6:26801.

29. Johnson-Wood K, Lee M, Motter R, Hu K, Gordon G, Barbour R, Khan K, Gordon M, Tan H, Games D, Lieberburg I, Schenk D, Seubert P, McConlogue L. Amyloid precursor protein processing and $A \beta_{42}$ deposition in a transgenic mouse model of Alzheimer disease. Proc Natl Acad Sci USA. 1997;94: $1550-5$.

30. Kitamoto T, Tateishi J, Tashima T, Takeshita I, Barry RA, Dearmond SJ, Prusiner SB. Amyloid plaques in Creutzfeldt-Jakob disease stain with prion protein antibodies. Ann Neurol. 1986;20:204-8.

31. Kokjohn TA, Van Vickle GD, Maarouf CL, et al. Chemical characterization of pro-inflammatory amyloid-beta peptides in human atherosclerotic lesions and platelets. Biochim Biophys Acta. 2011;1812:1508-14.
32. Kuhlmann J, Andreasson U, Pannee J, Bjerke M, Portelius E, Leinenbach A, Bittner T, Korecka M, Jenkins RG, Vanderstichele H, Stoops E, Lewczuk P, Shaw LM, Zegers I, Schimmel H, Zetterberg $\mathrm{H}$, Blennow K, On behalf of the IFCC Working Group on standardization of CSF proteins (WG-CSF). CSF $\mathrm{A} \beta_{1-42}$ - an excellent but complicated Alzheimer's biomarker-a route to standardisation. Clin Chim Acta. 2017;467:27-33.

33. Lachno DR, Vanderstichele H, De Groote G, Kostanjevecki V, De Meyer G, Siemers ER, Willey MB, Bourdage JS, Konrad RJ, Dean RA. The influence of matrix type, diurnal rhythm and sample collection and processing on the measurement of plasma beta-amyloid isoforms using the INNO-BIA plasma $A \beta$ forms multiplex assay. J Nutr Health Aging. 2009;13:220-5.

34. Lambert JC, Schraen-Maschke S, Richard F, Fievet N, Rouaud O, Berr C, Dartigues JF, Tzourio C, Alpérovitch A, Buée L, Amouyel P. Association of plasma amyloid beta with risk of dementia: the prospective Three-City Study. Neurology. 2009;73: 847-53.

35. Liebsch F, Kulic L, Teunissen C, Shobo A, Ulku I, Engelschalt V, Hancock MA, van der Flier WM, Kunach P, Rosa-Neto P, Scheltens P, Poirier J, Saftig P, Bateman RJ, Breitner J, Hock C, Multhaup G. $\mathrm{A} \beta 34$ is a BACE1-derived degradation intermediate associated with amyloid clearance and Alzheimer's disease progression. Nat Commun. 2019;10(1): 2240.

36. Masters CL, Simms G, Weinman NA, Multhaup G, McDonald BL, Beyreuther K. Amyloid plaque core protein in Alzheimer disease and Down syndrome. Proc Natl Acad Sci USA. 1985;82:4245-9.

37. Mattsson $\mathrm{N}$, Zetterberg $\mathrm{H}$, Janelidze $\mathrm{S}$, Insel PS, Andreasson U, Stomrud E, Palmqvist S, Baker D, Tan Hehir CA, Jeromin A, Hanlon D, Song L, Shaw LM, Trojanowski JQ, Weiner MW, Hansson O, Blennow K. On behalf of the ADNI Investigators. Plasma tau in Alzheimer disease. Neurology. 2016;87:1827-35.

38. Merlini G, Bellotti V. Molecular mechanisms of amyloidosis. N Engl J Med. 2003;349:583-96.

39. Mielke MM, Hagen CE, Xu J, Chai X, Vemuri $P$, Lowe VJ, Airey DC, Knopman DS, Roberts RO, Machulda MM, Jack CR Jr, Petersen RC, Dage JL. Plasma phospho-tau181 increases with Alzheimer's disease clinical severity and is associated with tauand amyloid-positron emission tomography. Alzheimers Dement. 2018;14:989-97.

40. Morgan AR, Touchard S, Leckey C, O'Hagan C, Nevado-Holgado AJ, Barkhof F, Bertram L, Blin O, Bos I, Dobricic V, Engelborghs S, Frisoni G, Frölich 
L, Gabel S, Johannsen P, Kettunen P, Kłoszewska I, Legido-Quigley C, Lleó A, Martinez-Lage P, Mecocci P, Meersmans K, Molinuevo JL, Peyratout G, Popp J, Richardson J, Sala I, Scheltens P, Streffer J, Soininen H, Tainta-Cuezva M, Teunissen C, Tsolaki M, Vandenberghe R, Visser PJ, Vos S, Wahlund L-O, Wallin A, Westwood S, Zetterberg H, Lovestone S, Morgan BP, NIMA Consortium. Annex: NIMA-Wellcome Trust Consortium for Neuroimmunology of Mood Disorders and Alzheimer's Disease. Inflammatory biomarkers in Alzheimer's disease plasma. Alzheimers Dement. 2019;15:776-87.

41. Nakamura A, Kaneko N, Villemagne VL, Kato T, Doecke J, Doré V, Fowler C, Li QX, Martins R, Rowe C, Tomita T, Matsuzaki K, Ishii K, Ishii K, Arahata Y, Iwamoto S, Ito K, Tanaka K, Masters CL, Yanagisawa $K$. High performance plasma amyloid- $\beta$ biomarkers for Alzheimer's disease. Nature. 2018;554(7691): 249-54.

42. Nelson PT, Dickson DW, Trojanowski JQ, Jack CR, Boyle PA, Arfanakis K, Rademakers R, Alafuzoff I, Attems J, Brayne C, Coyle-Gilchrist ITS, Chui HC, Fardo DW, Flanagan ME, Halliday G, Hokkanen SRK, Hunter S, Jicha GA, Katsumata Y, Kawas CH, Keene CD, Kovacs GG, Kukull WA, Levey AI, Makkinejad N, Montine TJ, Murayama S, Murray ME, Nag S, Rissman RA, Seeley WW, Sperling RA, White Iii CL, Yu L, Schneider JA. Limbic-predominant age-related TDP-43 encephalopathy (LATE): consensus working group report. Brain. 2019;142: 1503-27.

43. O'Brien RJ, Wong PC. Amyloid precursor protein processing and Alzheimer's Disease. Annu Rev Neurosci. 2011;34:185-204.

44. O'Bryant SE, Mielke MM, Rissman RA, Lista S, Vanderstichele $\mathrm{H}$, Zetterberg $\mathrm{H}$, Lewczuk P, Posner H, Hall J, Johnson L, Fong Y-L, Luthman J, Jeromin A, Batrla-Utermann R, Villarreal A, Britton G, Snyder PJ, Henriksen K, Grammas P, Gupta V, Martins R, Hampel H, Biofluid Based Biomarker Professional Interest Area. Blood-based biomarkers in Alzheimer disease: current state of the science and a novel collaborative paradigm for advancing from discovery to clinic. Alzheimers Dement. 2017;13:45-58.

45. Olsson A, Vanmechelen E, Vanderstichele $H$, Davidsson P, Blennow K. Unaltered plasma levels of $\beta$-amyloid $(1-40)$ and $\beta$-amyloid $(1-42)$ upon stimulation of human platelets. Dement Geriatr Cogn Disord. 2003;16:93-7.

46. Olsson B, Lautner R, Andreasson U, Öhrfelt A, Portelius E, Bjerke M, Hölttä M, Rosén C, Olsson C, Strobel G, Wu E, Dakin K, Petzold M, Blennow K, Zetterberg H. CSF and blood biomarkers for the diagnosis of Alzheimer's disease: a systematic review and meta-analysis. Lancet Neurol. 2016;15: 673-84.
47. Ovod V, Ramsey KN, Mawuenyega KG, Bollinger JG, Hicks T, Schneider T, Sullivan M, Paumier K, Holtzman DM, Morris JC, Benzinger T, Fagan AM, Patterson BW, Bateman RJ. Alzheimers Dement. 2017;13:841-9.

48. Palmqvist S, Janelidze S, Stomrud E, Zetterberg H, Karl J, Zink K, Bittner T, Mattsson N, Eichenlaub U, Blennow K, Hansson O. Performance of fully automated plasma assays as screening tests for Alzheimer disease-related $\beta$-amyloid status. JAMA Neurol. 2019.

49. Piccarducci R, Pietrobono D, Pellegrini C, Daniele S, Fornai M, Antonioli L, Trincavelli ML, Blandizzi C, Martini C. High levels of $\beta$-amyloid, tau, and phospho-tau in red blood cells as biomarkers of neuropathology in senescence-accelerated mouse. Oxid Med Cell Longev. 2019;5030475.

50. Pirttilä T, Kim KS, Mehta PD, Frey H, Wisniewski HM. Soluble amyloid beta-protein in the cerebrospinal fluid from patients with Alzheimer's disease, vascular dementia and controls. J Neurol Sci. 1994;127:90-5.

51. Risacher SL, Fandos N, Romero J, Sherriff I, Pesini P, Saykin AJ, Apostolova LG. Plasma amyloid beta levels are associated with cerebral amyloid and tau deposition. Alzheimers Dement (Amst). 2019;26(11):510-9.

52. Roher AE, Esh CL, Kokjohn TA, et al. Amyloid beta peptides in human plasma and tissues and their significance for Alzheimer's disease. Alzheimers Dement. 2009;5:18-29.

53. Rózga M, Bittner T, Batrla R, Karl J. Preanalytical sample handling recommendations for Alzheimer's disease plasma biomarkers. Alzheimers Dement (Amst). 2019;11:291-300.

54. Rup B, O'Hara D. Critical ligand binding reagent preparation/selection: when specificity depends on reagents. AAPS J. 2007;9:E148-55.

55. Scheltens P, Rockwood K. How golden is the gold standard of neuropathology in dementia? Alzheimers Dement. 2011;7:486-9.

56. Schindler SE, Bollinger JG, Ovod V, Mawuenyega KG, Li Y, Gordon BA, Holtzman DM, Morris JC, Benzinger TLS, Xiong C, Fagan AM, Bateman RJ. High-precision plasma $\beta$-amyloid $42 / 40$ predicts current and future brain amyloidosis. Neurology. 2019.

57. Sergeant N, Bombois S, Ghestem A, Drobecq $H$, Kostanjevecki V, Missiaen C, Wattez A, David J-P, Vanmechelen E, Sergheraert C, Delacourte A. Truncated beta-amyloid peptide species in preclinical Alzheimer's disease as new targets for the 
vaccination approach. J Neurochem. 2003;85: 1581-91.

58. Sevalle J, Amoyel A, Robert P, Fournie-Zaluski MC, Roques B, Checler F. Aminopeptidase A contributes to the N-terminal truncation of amyloid $\beta$-peptide. J Neurochem. 2009;109:248-56.

59. Shaw LM, Arias J, Blennow K, Galasko D, Molinuevo JL, Salloway S, Schindler S, Carrillo MC, Hendrix JA, Ross A, Illes J, Ramus C, Fifer S. Appropriate use criteria for lumbar puncture and cerebrospinal fluid testing in the diagnosis of Alzheimer's disease. Alzheimers Dement. 2018;14: $1505-21$

60. Silverberg N, Elliott C, Ryan L, Masliah E, Hodes R. NIA commentary on the NIA-AA research framework: towards a biological definition of Alzheimer's disease. Alzheimers Dement. 2018;14:576-8.

61. Stoops E, Verberk I, Thijssen E, Koelewijn J, Scheltens P, van der Flier WM, Teunissen CE, Vanderstichele HM. Pre-analytical stability study of plasma amyloid beta 1-42 and 1-40 measured by a novel Simoa assay. AAIC Featured Research Session, July 14th, 2019.

62. Teunissen CE, Petzold A, Bennett JL, Berven FS, Brundin L, Comabella M, Franciotta D, Frederiksen JL, Fleming JO, Furlan R, Hintzen RQ, Hughes SG, Johnson MH, Krasulova E, Kuhle J, Magnone MC, Rajda C, Rejdak K, Schmidt HK, van Pesch V, Waubant E, Wolf C, Giovannoni G, Hemmer B, Tumani $\mathrm{H}$, Deisenhammer F. A consensus protocol for the standardization of cerebrospinal fluid collection and biobanking. Neurology. 2009;73:1914-22.

63. Teunissen CE, Otto M, Engelborghs S, Herukka S-K, Lehmann S, Lewczuk P, Lleó A, Perret-Liaudet A, Tumani H, Turner MR, Verbeek MM, Wiltfang J, Zetterberg H, Parnetti L, Blennow K. White paper by the Society for CSF Analysis and Clinical Neurochemistry: Overcoming barriers in biomarker development and clinical translation. Alzheimers Res Ther. 2018;10:30.

64. Vanderstichele $H$, De Meyer $G$, Andreasen $N$, Kostanjevecki V, Wallin A, Olsson A, Blennow K, Vanmechelen E. Amino-truncated $\beta$-amyloid 42 peptides in cerebrospinal fluid and prediction of progression of mild cognitive impairment. Clin Chem. 2005;51:1650-60.

65. Vanderstichele H, Bibl M, Engelborghs S, Le Bastard N, Lewczuk P, Molinuevo JL, Parnetti L, Perret-Liaudet A, Shaw LM, Teunissen C, Wouters D, Blennow K. Standardization of preanalytical aspects of cerebrospinal fluid biomarker testing for Alzheimer's disease diagnosis: a consensus paper from the Alzheimer's Biomarkers Standardization Initiative. Alzheimers Dement. 2012;8:65-73.
66. Vanderstichele HMJ, Janelidze S, Demeyer L, Coart E, Stoops E, Herbst V, Mauroo K, Brix B, Hansson O. Optimized standard operating procedures for the analysis of cerebrospinal fluid $A \beta_{42}$ and the ratios of $\mathrm{A} \beta$ isoforms using low protein binding tubes. J Alzheimers Dis. 2016;53:1121-32.

67. van Oijen M, Hofman A, Soares HD, Koudstaal PJ, Breteler MM. Plasma Abeta(1-40) and Abeta(1-42) and the risk of dementia: a prospective case-cohort study. Lancet Neurol. 2006;5:655-60.

68. Verberk IMW, Slot RE, Verfaillie SCJ, Heijst H, Prins ND, van Berckel BNM, Scheltens P, Teunissen CE, van der Flier WM. Plasma amyloid as prescreener for the earliest Alzheimer pathological changes. Ann Neurol. 2018;84:648-58.

69. Vergallo A, Mégret L, Lista S, Cavedo E, Zetterberg $\mathrm{H}$, Blennow K, Vanmechelen E, De Vos A, Habert M-O, Potier M-C, Dubois B, Neri C, Hampel H, INSIGHT-preAD study group, for the Alzheimer Precision Medicine Initiative (APMI). Plasma amyloid $\beta$ 40/42 ratio predicts cerebral amyloidosis in cognitively normal individuals at risk for Alzheimer's disease. Alzheimers Dement. 2019;15:764-75.

70. Wildburger NC, Esparza TJ, LeDuc RD, Fellers RT, Thomas PM, Cairns NJ, Kelleher NL, Bateman RJ, Brody DL. Diversity of amyloid-beta proteoforms in the Alzheimer's disease brain. Sci Rep. 2017;7:9520.

71. Willemse EAJ, Teunissen CE. Biobanking of cerebrospinal fluid for biomarker analysis in neurological diseases. Adv Exp Med Biol. 2015;864:79-93.

72. Wiltfang J, Esselmann H, Bibl M, Hüll M, Hampel H, Kessler H, Frölich L, Schröder J, Peters O, Jessen F, Luckhaus C, Perneczky R, Jahn H, Fiszer M, Maler JM, Zimmermann R, Bruckmoser R, Kornhuber J, Lewczuk P. Amyloid $\beta$ peptide ratio $42 / 40$ but not A $\beta 42$ correlates with phospho-Tau in patients with low- and high-CSF A 340 load. J Neurochem. 2007;101:1053-9.

73. Yang L, Rieves D, Ganley C. Brain amyloid imagingFDA approval of florbetapir F18 injection. N Engl J Med. 2012;367:885-7.

74. Zakharova NV, Bugrova AE, Kononikhin AS, Indeykina MI, Popov IA, Nikolaev EN. Mass spectrometry analysis of the diversity of $A \beta$ peptides: difficulties and future perspectives for $\mathrm{AD}$ biomarker discovery. Expert Rev Proteomics. 2018;15: $773-5$.

75. Zetterberg H, Wilson D, Andreasson U, Minthon L, Blennow K, Randall J, Hansson O. Plasma tau levels in Alzheimer's disease. Alzheimers Res Ther. 2013;28(5):9. 